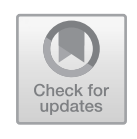

\title{
The Role of Media Within Young People's Socialisation: A Theoretical Approach
}

\subsection{INTRODUCTION}

Contemporary societies are characterised by rapid social change, which is furthered by developments in media and technology. Mediatization, as a societal meta-process (Krotz \& Hepp, 2013; Livingstone \& Lunt, 2014), is regarded as a highly "transformative process" (Silverstone, 2002, p. 761 ); it refers to "how changes occur when communication patterns are transformed due to the communication tools and technologies" (Lundby, 2014 , p. 3). Mediatization has not only changed the everyday lives of adults but accompanies far-reaching changes in the lives of children and adolescents. In Western societies at least, media are omnipresent companions in the everyday lives of young people, at home and at school, during training and in leisure time. From the earliest years of childhood, today's young people are confronted with media devices and media content in a vast diversity that would have been nearly inconceivable in previous generations. Rideout refers to the growth in media activities among children as "phenomenal" (2016, p. 138). As with adult life, contemporary childhood and youth are, in their essence, deeply mediatised (Hasebrink \& Paus-Hasebrink, 2013; Livingstone, 2014). Such increasing mediatization means that we need to understand how it is transforming the interplay of structural and individual aspects in everyday life for young people (see Hoffmann, Krotz, \& Reißmann, 2017, p. 7). What does this mean for research that sets out to understand young people's socialisation?

(C) The Author(s) 2019

I. Paus-Hasebrink et al., Social Inequality, Childhood and the Media, Transforming Communications - Studies in Cross-Media Research, https://doi.org/10.1007/978-3-030-02653-0_3 
Due to the increasing relevance of mediatization in society as a whole, and for young people in particular, scholars have to pay attention to the ways in which adolescents relate to media in the course of their everyday socialisation: "It seems rather obvious to state that children's use of media and exposure to media content does not happen in a vacuum, it occurs in the wider contexts in which they live their lives" (Vandewater, 2013 , p. 51). Therefore, researching the role of media in socialisation requires an integrative approach that conceptualises socialisation as a contextual, interwoven process, in which children and adolescents construct their approach to life against the background of the specific social place, in which they grow up, and of their psycho-social development as individuals. On this basis, we will argue that we need to conceptualise and operationalise socialisation in terms of the interaction between the individual child, or, respectively, adolescent, and the relevant contexts of its growing up. This seems necessary because of the two parent disciplines underpinning previous research on socialisation: psychology, which discusses the individual side of socialisation processes, and sociology, which sheds light on the socio-structural side. Both have long been characterised by their isolated and specific disciplinary perspectives (for a deeper insight, see Prout, 2008). They do, however, have two things in common: firstly, viewing several socialisation agents as "next to" others (for examples of this, see Prout et al., 2015), particularly parents and peers, educational institutions and extracurricular socialisation agents, and such as youth centres, secondly, by and large they do not attend to media at all. This is unsatisfactory because children grow up in interwoven contexts, all of which are saturated by media.

Before we look at socialisation processes as they relate to media and communications, we will discuss the relevant perspectives of psychology and sociology, in order to bolster our argument on the need for an interactive perspective on the process of socialisation in general.

\subsection{SOCIALISATION From DifFERENT Disciplinary Perspectives}

Psychology and/or sociology have developed theories on socialisation from an individual and/or societal perspective, and further research on socialisation processes derives from them.

Many contemporary theories and models dealing with the psychology of personality have substantial biological components (Krueger \& 
Johnson, 2010). And a field recently become popular, neuroscience and genetics, also offers insights, which play an important role in understanding human behaviour (Grusec \& Hastings, 2015, p. xii). Here, the focus is on the interdependence between biological conditions and experiences, an issue also relevant in socialisation research. While we acknowledge the relevance of biological conditions, we will not discuss them in more detail, because our main objective in this chapter is to conceptualise the way children are situated in their relevant contexts.

\subsubsection{Socialisation from a Psychological Perspective}

From the psychological perspective, socialisation has been described using such examples as the maturationist theory (for example, Gesell, 1933), constructivist theories (for example, Bruner, Goodnow, \& Austin, 1962; Piaget, 1980; Wygotski, 1977), psychodynamic theories (for example, Freud, see Mayer, 2017; Erikson, 1959, 1968; Adler, see Hoffman, 1994) and ecological theory (for example, Bronfenbrenner, 1977, 1979).

The history of psychology suggests that psychoanalysis has tended to neglect how people perform as active agents. The perspective of agency has not been considered relevant in the psychology of perception and in cognitive psychology until the cognitive turn of the last forty years. These theories then proceeded to reject biological models of personality development and instead examined social and societal influences, returning to the active subject as premise. Agency has also been considered relevant in the developmental psychology pioneered by Piaget, which focuses on the "physical, cognitive, and social-emotional changes that occur during the life span" (Piotrowski \& Valkenburg, 2016, p. 1). Bronfenbrenner developed Piaget's thoughts into an "ecological model" to place the ecology of human development in the context "of the progressive, mutual accommodation, throughout the life span, between a growing human organism and the changing immediate environments in which it lives, as this process is affected by relations obtaining within and between these immediate settings, as well as the larger social contexts, both formal and informal, in which the settings are embedded" (1977, p. 514). This viewpoint sees human development taking place within "a set of social contexts, including local ones such as family, household and neighbourhood, and more distant ones such as social structure and policy" (Prout, 2008, p. 28). The revised Ecological Systems Theory 
(EST) (Neal \& Neal, 2013) describes children's development in the context of several environmental systems, which can be seen as an overlapping arrangement of structures. This model constructs social contexts as "environments", in which individuals develop their identities on the basis of social patterns. According to these theories, socialisation is a "bidirectional process" (Smetana, Robinson, \& Rote, 2015, p. 60): “The shift is part of the more general change from the top-down perspective of early behaviourists and psychoanalytic theories to interactive viewpoints which place increasing emphasis on the agency of the child as well as the parent in socialization" (Maccoby, 2015, p. 25). However, EST does not cover the process of transforming social contexts into personal characteristics.

\subsubsection{Socialisation from a Sociological Perspective}

Sociology's initial theories on socialisation considered how an individual may internalise successfully social values and norms (Abels, 2015). Abels emphasised that the verb "to socialise" had first arisen in 1846 and meant "to make fit for living in society" (Abels, 2015, p. 51). Sociology looked for aspects of social order (for example, Cooley, 1902); Simmel (1908) and researched different forms of sociality and social control. For many years, sociology focused on individuals as objects (or even victims) of external, societally determined influences on their socialisation. According to a functionalist point of view (Durkheim, 1972), individuals were believed to simply adopt the roles given to them. Parsons focused on the relevance of the roles and norms dominating society; in this sense socialisation means integration into a social order as default setting (Parsons, 1951).

However, the concept of socialisation has changed since the end of the 1960s, initiated by the idea of an "active subject" (see for overview Hurrelmann, Bauer, Grundmann, \& Walper, 2015). Theories of action were developed by Berger and Luckmann (1966), who based their work on Weber (see Schöllgen, 1998), and Mead (1934). Berger and Luckmann outlined the reality of everyday life as "an intersubjective world, a world that I share with others" (1966, p. 37). They showed how social reality is constituted through social actions and can be understood as the practice of everyday life, which, in turn, influences the development of individual actors.

During the 1980s, the socialisation researcher Klaus Hurrelmann (2009) developed these insights into a model of "productive processing 
of reality" that connects sociological and psychological elements. Hurrelmann states that "personality does not form independently from society any of its functions or dimensions but is continuously being shaped, in a concrete, historically conveyed life world, throughout the entire space of the life span" (Hurrelmann, 2009, p. 42). This model puts the human subject into a social and ecological context, which is subjectively perceived and processed. While the social and ecological contexts influence individuals, the latter also always influence, change and co-create the former (Hurrelmann \& Bauer, 2015). Thus, this approach is characterised by a multi-dimensional perspective, taking into account both subjective and objective factors of personality development. The objective factors are the circumstances of the social and physical environment (exterior reality), whereas the subjective factors encompass a subject's bodily and mental qualities and traits (interior reality). From this perspective, children are neither "becomings" nor "full beings" (James, Jenks, \& Prout, 1998) but "active constructers of social knowledge" (Laible, Thomson, \& Froimson, 2015, p. 47).

Whether emphasis is placed on individual or social perspectives, socialisation is always an "interactive process" (Hurrelmann \& Bauer, 2015, p. 146) and is contextualised in a dynamic process of interwoven macro and microstructural factors within the framework of social interaction between individuals and the specific social context of their everyday lives. Specific practices of socialisation are mainly developed in social contexts (for example, family, peers or friendships), in institutional contexts (for example, kindergarten, schools, job training), or in non-institutional, recreational contexts. Communicative practices, including media-based practices, are developed as integral parts of these social practices.

\subsubsection{Perspectives on the Process of Socialisation in Media and Communications Research}

Media and communications research provides rich empirical evidence on young people's use of media devices and products (for example, Lauricella, Cingel, Blackwell, Wartella, \& Conway, 2014; Rideout, Foehr, \& Roberts, 2010). Particularly in recent years, many researchers have fundamentally questioned how children use media within their process of identity construction (Buckingham, 2008; see Hoffmann et al., 2017, p. 6). 
Studies show that children and adolescents use media to acquire a view of the world, to build contacts with peers and friends, and to deal with the self (Paus-Hasebrink, 2010; Subrahmanyam \& Šmahel, 2011). As agencies of symbols and meanings, media offer children orientation and the potential for identification (Lemish, 2007; Livingstone \& Bovill, 2001; Paus-Hasebrink \& Kulterer, 2014), and the internet offers a particularly wide range of opportunities for self-presentation. When using "the Internet the self is presented without bodily presence $[(\ldots])$, the presentation of the self requires resources to mediate not only the setting and appearance but also the manners, the dramatic realization" (Skaar, 2009 , p. 252).

Media can have a supporting function in young people's socialisation and further the development of social understanding (Livingstone, d'Haenens, \& Hasebrink, 2001, p. 5; Paus-Hasebrink \& Kulterer, 2014). This "means they can offer children stimuli and suggestions for an active engagement with themselves and their surroundings" (Charlton \& Neumann, 1986, p. 32). In formal education, inserting "popular culture, media and/or new technologies into the communications, language and literacy curriculum have a positive effect on the motivation and engagement of children in learning" (Marsh et al., 2005, p. 6).

In addition, many researchers have, particularly in recent years, questioned how, given the background of different social contexts they are involved in, children and adolescents make sense of media within their everyday life. So, such research fundamentally investigates how children use media within their process of identity construction (Buckingham, 2008; see Hofmann et al., 2017, p. 6). Here, Drotner, and Livingstone (2008) and Lemish (2013), for example, have made a positive advance by demonstrating how research is needed to "strengthen the depth of contextualisation within studies of media and of childhood both in theoretical and empirical terms" (Drotner \& Livingstone, 2008, p. 4). With reference to increasing mediatization, we have to take transformation processes within the interplay of structural and individual aspects of young people's everyday life into account and show how they interact (see Hofmann et al., 2017, p. 7). Therefore, it is not sufficient to do cross-sectional research only, because this cannot trace how socialisation processes occur over a number of years and indicate which roles different media play within this process. In order to understand young people holistically as they engage in a range of specific social contexts (see Furlong \& Davies, 2012), we need, on the one hand, a theoretical 
approach, taking into account immediate and broader social contexts and providing deeper insights into the interplay between relevant contexts within the process of socialisation (James, 2013). These questions correspond to Ien Ang's understanding of contextualism (2006). As she emphasises, the key challenge for such an approach is to identify the relevant contexts, which shape the structure of the child's everyday life (Ang, 2006 , p. 69). On the other hand, we need a methodology which is able to empirically show how the process of transfer between social contexts and personal characteristics - and vice versa-takes place within young people's socialisation processes as they grow up, in order to illustrate these interactions in relation to the role of media within socialisation. Against this background, we intend to deal more broadly with socialisation within children's and adolescents' relevant socio-cultural contexts (see Wartella et al., 2016) and to shed light on the role of media in today's mediatised socialisation. This approach takes account of the fact that media infiltrate all contexts of socialisation, considered here as a contextual, interlinked process. In it, children and adolescents construct their approach to life against the background of the specific social situation in which they are growing up and of their individual biological and psycho-social development.

In order to examine these processes, we will firstly discuss the concept of developmental tasks. Secondly, we will focus on the family as the most relevant social context for most children and adolescents, which at the same time also reflects the other social contexts, such as peers and friendships, institutional contexts like kindergarten, school, job training and non-institutional, recreational contexts. Thirdly, we propose, therefore, a praxeological approach built on three analytical concepts developed by Paus-Hasebrink (see, for example, Paus-Hasebrink, 2017, 2018), which help to analyse the interaction between the individual child and its social contexts and are based on Bourdieu's "Theory of Practice" (1977; see also Weiß, 2000).

\subsection{On the Role of Developmental Tasks in the Framework of Socialisation Processes}

At the centre of an adolescent's socialisation is the process of identity formation, in which it develops its personal as well as its social identity (Erikson, 1968; Krappmann, 2016). According to Erikson, identity construction is a basis for growing up: "In the social jungle of 
human existence there is no feeling of being alive without a sense of identity" (1970). Against the theoretical framework of developmental tasks, as presented by Havighurst (1972), children grow up and learn to deal with the age-specific challenges they encounter in their everyday lives. Development is conceived of as a learning or working process. In order to cope with the relevant developmental tasks related to the different stages of growing up and with various daily life experiences, young people seek to acquire expertise. Hence the process of growing up is built on dealing un/successfully with developmental tasks, for example building stable social relationships with peers and dealing with the self. "Erving Goffman describes "the presentation of self in everyday life' (1959) as a perpetual process of social performance" (Skaar, 2009, p. 251). Developmental tasks-closely linked to children's and adolescents' age, gender and social background-shape their perception and action when dealing with their environment. This process takes place within the framework of developmental tasks shaped by a person's biography and guiding an individual's perception, cognition and action (Havighurst, 1972), while not wholly determining it. "A developmental task is a task which arises at or about a certain period in the life of the individual, successful achievement of which leads to his happiness and to success with later tasks, while failure leads to unhappiness in the individual, disapproval by the society, and difficulty with later tasks" (Havighurst, 1972, p. 2). This concept was developed within developmental psychology and has since been frequently applied to societal changes and adapted to explain them (see Hurrelmann, 2009). For our purposes, it serves as a relevant insight into how children build their identity in the context of their everyday lives. Heckhausen and Schulz (1999) have stressed that Havighurst's concept does not only apply to children but to adults as well. In order to distinguish between children's and adults' tasks, we use the term developmental tasks with reference to children and the term life tasks with reference to adults.

\subsubsection{Childhood and Adolescence-Move Than Age-Based Phases}

The concept of developmental tasks recognises children's active role in co-constructing the symbolic and material world in which they live and grow up (James et al., 1998). At the same time, it reflects James' (2013, p. 15) recent argument that children's individual agency has, in fact, been somewhat overemphasised, as children's agency cannot fully 
override socio-structural conditions. Following this perspective, identity formation can be regarded as a dynamic process of construction, in which children form their beliefs and their attitudes towards themselves, including cognitive, emotional and motivational components. In this process, a child is confronted with basic challenges that arise from his or her particular situation and biographical context: the "developmental tasks" (Havighurst, 1972). These tasks include finding one's place in life, learning about oneself by relating to others, and interacting with and positioning oneself within the family, the peer group, and other social contexts (Hurrelmann, 2009, p. 42).

When children grow older, they have to cope with the special challenges of adolescence; socialisation research calls this phase a "distinct developmental period" (Smetana et al., 2015, p. 60).

Historically, the phase of adolescence is a fairly recent concept. A transitional phase between childhood and adulthood has been identified since antiquity, but in its current form this phase is the result of massive changes in productive and social structures caused by the industrial revolution in Western societies. In this sense, adolescence has developed into a phase not marked by gainful work, but by education and preparation for adulthood (see Kimmel \& Weiner, 1995, p. 7; Oerter \& Dreher, 2008 , p. 271). During the post-war years especially, adolescence continued to be differentiated and has expanded at the expense of adulthood, until it has today become a central phase in an individual's life cycle (see Hurrelmann, 2010, pp. 17, 36).

In terms of its duration, the phase of adolescence is very ambiguous and hard to define. Simple age in years is often used to set its boundaries, especially in legal contexts, but a look at the extensive literature on it shows that definitions vary greatly with regard to any framing by age (see Göppel, 2005, pp. 3-5). On the social level, many societies maintain certain rites of passage (often linked to religious rituals like, for example, the bar mitzvah or the Christian confirmation) that mark the beginning of adolescence. Other definitions concentrate on biological factors to mark at least the beginning of adolescence with the beginning of the biological and physical changes associated with puberty, which do not always correspond with definitions based on age, since such development varies among individuals (see Kimmel \& Weiner, 1995, pp. 2-3).

Each and every age-based definition is, thus, first and foremost an artificial and pragmatic limitation and does not necessarily correspond with an individual's reality. It is, therefore, much more feasible to focus 
on a definition that concentrates on shared patterns of experiences or crises, in the sense of developmental tasks as characteristic for adolescence in today's society. In this sense, dealing with the same developmental challenges can be used as a marker to subsume individuals in the same developmental phase. At the same time, it must be pointed out that youth or adolescents do not exist as a homogenous mass; even with shared developmental tasks, these collective terms cover a heterogeneous group of individuals.

\subsubsection{Adolescence-A Phase of Transition}

What most definitions of adolescence do, however, have in common, is the notion of transition, the transition between childhood and adulthood (Kimmel \& Weiner, 1995, p. 15). Where young people have to cope with "with unstable forms of community integration, identity is seen as much more dynamic, multiplistic, relativistic, fluid, context-specific, and fragmented" (Mayseless \& Keren, 2014, p. 64). Arnett (2007, p. 69) describes the end of this phase of transition as a time "between": "no longer adolescent but only partly adult, emerging into adulthood but not there yet" (Arnett, 2007, p. 70). This phase is characterised by "unsettledness, exploration, and instability" (Arnett, 2006, p. 7). Issues such as the context in which this transition takes place, what is expected from adolescents and what is deemed "successful" or "unsuccessful" coping with developmental tasks are subject to cultural and historic differences (see Kimmel \& Weiner, 1995, p. 4).

In 1972, Havighurst first formulated developmental tasks that are specific to various periods in life. His work serves as the basis for later adaptations that account for social changes in the years since the tasks were first formulated. Despite social changes in the past decades, literature shows that the core topics remain fairly stable, but recently we have observed that dealing with certain tasks is being pushed backwards by dint of, for example, longer periods in education and a later entry into work, women becoming mothers at a later age and so on, all coupled with changing priorities (see Fend, 2005, p. 152; Noller \& Atkin, 2014, pp. 5-10; Oerter \& Dreher, 2008, p. 283). Mayseless and Keren (2014) point out coping with love and work as the central developmental task: “(...) love and work, are described as the focus of identity exploration in emerging adulthood. (...) Current postmodern processes in Western industrialized countries set the stage for the saliency of a new 
developmental task in emerging adulthood: finding the meaningful life" (Mayseless \& Keren, 2014, p. 63). With regard to Havighurst's conception, and to further differentiations from other authors, we can subsume the relevant developmental tasks for adolescents in today's Western societies as follows: coming to terms with one's body, establishing and negotiating relationships with peers, forming an idea of one's role in society, developing first romantic relationships, dealing with one's sexual identity, detachment/independence from parents, gathering resources to build a personal economic basis, developing an idea of one's self, obtaining values, thinking about forming a family and making plans for the future (see Havighurst, 1972, p. 45; Kimmel \& Weiner, 1995, pp. 15f.; Noller \& Atkin, 2014, pp. 2-10; Oerter \& Dreher, 2008, p. 279).

\subsection{3 "Meta-Developmental Tasks"}

Above all this stands one large "meta-developmental task" (Friedemann \& Hoffmann, 2013, p. 375; translated by the authors) that basically influences all other areas and tasks: the construction of a unique identity to set oneself apart from others (see Friedemann \& Hoffmann, 2013, p. 375). It can be argued that this task is one that continues throughout life, and one's identity is, in this context, never ultimately fixed. Nevertheless, the phase of adolescence is where this task becomes especially prominent.

Young people often live under particular pressure (see Quenzel, 2015, p. 23); they have to cope with many changes, both on an individual and a social level. When we look at the employment market and the insecure employment situations today, it is evident that young people have to face numerous demanding situations, such as the need for flexibility and more and more higher qualifications. Hence, the task of acquiring qualifications for a career has gained importance in recent years. This is highly relevant for less educated adolescents especially and frequently leads to pressure on them to perform (see Albert, Hurrelmann, \& Quenzel, 2015, p. 40). So, socially disadvantaged young people often have to deal with frustration and disappointment (see Quenzel, 2015, p. 23). Confronting situations like these leads to strain and emotional pressure and quite often to capacity overload. In this context, Quenzel talks about another relevant developmental task for young people: they have to know how to recuperate and to relax and, in this context, to manage leisure time competently and deal with consumer culture (see Quenzel, 2015, p. 34). 


\subsubsection{Developmental Tasks and Media Contexts}

By coping with developmental tasks, young people develop and stabilise their capacity for action. Where they are confronted with specific developmental tasks during the socialisation process, they attribute specific meanings to media and communicative practices. The context for coping with developmental tasks is an individual's everyday life. In this sense, young people are always moving in fields of tension and are challenged by crises, which can also be understood as possible turning points. They must cope with these challenges to make daily life liveable. To do so, they require information and orientation, as well as support, and counsel. The process often includes an increased desire for experience, while such desires and needs also typify an individual adolescent's situation in the world. Against this backdrop, and the range of available media options, young people select media products and services based on their individual preferences and aversions and with regard to their usefulness in coping with everyday life challenges.

So far, we have discussed socialisation as the process of interaction between individual adolescents and their relevant social contexts. We have referred to the concept of developmental tasks to specify how children form identity by coping with these tasks, in part by using media. We will now proceed to examine the most relevant social context, the family, and its role in children's and young peoples' socialisation. As mentioned above, there are several relevant contexts, such as the family, peer-groups or friends (and later, romantic partners), institutional contexts, such as kindergarten, school or job training, alongside the overall societal context (Hurrelmann, 2009) and the media system (Lange, 2015). These contexts will be discussed later on by considering children's and parents' perspective on them against the background of our empirical data. As our study progressed, we focused on the family, because our empirical research indicated how the families of the children in our panel crystallised as the main socialisation context, and, with this, the fundamental basis for children in developing their view on the world. Against this background, the interaction between the individual children and their family contexts will be discussed more explicitly, before we present our empirical conceptualisation of our study. 


\subsection{The Family Context in Socialisation}

The family is the most relevant context of (most) young people's everyday lives because their lives are deeply embedded in it (see Noller \& Atkin, 2014). Keeping in mind that the concept of "family" cannot be understood as referring only to a stable, nuclear group of mother and father and children, we use this term in the wide sense of the core group, in which a child grows up. Particularly in early childhood, the family, and especially the parents, remain the most important actor in most children's socialisation (Grusec \& Hastings, 2015, p. xiii; Huston \& Wright, 1997). This also continues as they grow older and enter the often turbulent and challenging phase of adolescence (see Noller \& Atkin, 2014). Accordingly, we will now proceed to discuss children's and young people's socialisation in greater depth.

\subsubsection{On the Relevance of the Parent-Child Relationship}

We recognise the relevance of the interaction between family members (Goldberg, Grusec, \& Jenkins, 1999), given how the degree of proximity, trust and reciprocity that parents and children show towards each other shapes the styles of parenting and family communication. Parenting styles and practices are observable in the specific way parents interact with and manage their children and indicate how highly relevant they are to children's socialisation (Schofield Clark, 2013; Smetana et al., 2015 , p. 66). Given the correlation between parents' socio-structural background and their specific ways of interacting with their children and managing them, it can be assumed that the cognitive, social and cultural resources that parents acquire from their education, professional lives, and social networks influence their ability to support their children in their socialisation: the socio-cultural capital of parents shapes the acquisition of that capital by their children (Paus-Hasebrink, Bauwens, Dürager, \& Ponte, 2013). In this regard, we emphasise how families differ in their abilities to cope with and to support children in growing up and tackling their own developmental tasks, especially when they begin to seek independence and strive for individuality during adolescence (Noller \& Atkin, 2014, p. 2). 


\subsubsection{On the Relevance of Doing Family}

The ways family members interact with each other-Jordan calls this the "family system" (2003) — are connected to "family 'climate', family paradigms, family coordinated practices, and family myths and rituals" (Maccoby, 2015, p. 24). Analogously to what Livingstone and SeftonGreen (2016, p. 169) show for the area of education, this process may also have longer roots reaching back to earlier generations. This dynamic and affective process takes place every day, is continually renegotiated and reconstituted by the family members, and includes specific communication practices and media-based practices of sense-making. Taken together, these practices characterize the specific way of "doing family" (Morgan, 2011).

However, the process of doing family is influenced not only by children coping with biographically determined developmental tasks but also by the way their parents and other family members cope. In this process, the parents and/or other reference persons participate against the background of their own life tasks: for instance, they have to deal with the role distribution between mothers and fathers, to cope with the particular challenges of being a single parent or of unemployment, to manage potential new relationships, to find a balance between work life and family life, to fulfil their personal ambitions, or to maintain, or even improve, their position within the broader societal context. In this respect, the family also reflects other social contexts of children's socialisation, such as the neighbourhood, the parents' professional environment, and the family's position within the wider societal structure. In this way, the family sets the framework for a child's growing up and learning to deal with everyday challenges and to realise his or her own interests.

Furthermore, research also shows that there is a correlation between the relationships among family members, the ways in which they interact with each other, and the children's own ability to form their own relationships with peers, as well as in a romantic sense later in life. As Noller and Atkin (2014, p. 2) point out: "It appears that adolescents may model their dating relationships on what they have seen in relationship between their parents (Steinberg, 2005). Thus, adolescents whose families have poor relationships and relationships that are highly conflicted are less likely than those from harmonious families to learn the skills necessary for successful relationships outside the family. In addition, 
the quality of their adolescents' relationships with both parents and peers influences the quality of their romantic relationships (Brown, 2004)".

As regards media usage, a rich body of research on family communication and media has shown that a child's actions in general, and media related actions in particular, cannot be understood adequately without reflecting on families' specific modes of "doing family" (see, for example, Jennings \& Wartella, 2013; Lull, 1980; Wilson \& Drogos, 2013), which is, in turn, influenced by their socio-economic backgrounds. As Nathanson $(2013$, p. 304) emphasises, "family dynamics can shape children's vulnerability to the media and, likewise, media use can influence family dynamics".

Having said that, social contexts-the family as well as others-shape children's and adolescents' socialisation (Kimmel \& Weiner, 1995; Lamb, Ketterlinus, \& Fracasso, 1992, p. 465; Noller \& Atkin, 2014; see also Packer, 2017). Our study will demonstrate conclusively that we need to specify how these contexts, and the underlying social structures, are transformed into an individual child's personal orientation and identity. In the following section, we will propose a praxeological approach that allows us to understand how the socio-structural conditions influencing the everyday life of all members of a family are transformed into the specific ways children see and experience the world, how they orient themselves in this world, how they develop individual goals and plans, and, in doing so, how they make sense of media within their everyday life.

\subsection{A Praxeological Approach to Researching ChILdREN's Socialisation}

The following questions are central to the praxeological approach of researching the role of media within socialisation: How do children make sense of their media usage? How is this sense-making process connected to the children's interaction with their immediate reference persons in the context of the family? A fruitful starting point for our research lies in the perspective of Cultural Studies on society, individuals and the media: "The central emphasis here is not on the effects of the media on behaviour and attitudes, but on the ways in which meanings are established, negotiated and circulated (...) this research regards children's uses and interpretations of the media as inherently social processes to be 
characterized by forms of power and difference" (Buckingham, 2008, pp. 221-222).

However, as Ralph Weiß (2000) argues, research conducted in the sphere of Cultural Studies has not successfully demonstrated the link between the "maps of meanings", which show how subjects appropriate and interpret mediated points of view, and the practical rules that individuals use to organise their everyday lives in their specific social places (Weiß, 2000, p. 44). As early as 1992, David Morley, one of the proponents of Cultural Studies, stressed this point: "What is needed here is an approach that links differential interpretation back to the socio-economic structure of society, showing how members of different groups and classes, sharing different 'cultural codes', will interpret a given message differently not just at the personal, idiosyncratic level, but in a way systematically related to their socio-economic position" (Morley, 1992, p. 54). Nevertheless, the question of how social structures transform an individual's "subjective sense" remains a challenge for Cultural Studies because researchers lack a theory that systematically explains how to translate the objective structure of the relationship between power and social inequality into the subjective structure of points of view, habits of feeling and need to experience (Weiß, 2001, p. 12). The praxeological approach serves to answer this question.

Our focus is on young people and their reference persons in their everyday lives and thus in the particular social places that are materially and symbolically at their disposal. It is in these social places that individuals invest their "capital" and gain their competences for the action, through which they then make sense of everyday life, including, as one aspect of it, their use of media. In the following, we will set out the theoretical components of our approach systematically.

\subsubsection{The Lifeworld and Related Contexts}

As stated above, socialisation processes are shaped by social contexts, ranging from the inner circle of family and the most significant reference persons to the societal level characterised by the medially permeated political, economic and cultural contexts of a region or a country, such as the labour market, family-related laws and support programmes, educational institutions, and the availability of recreational facilities. Everyday life derives its specific character from the social situation of the family and the factors that characterise it: income, job, formal education and the 
living situation of the parents (Hradil, 1987). The social space in which the child learns to act is marked by the family's social situation, while that space's specific structure arises from the different fields of everyday life.

Socio-phenomenological or social-constructivist conceptions of everyday life provide an opportunity to avoid both a one-dimensional objectivist perspective on social phenomena and a purely subjectivist one. In his concept of the Lebenswelt, the "lifeworld", Alfred Schütz laid the foundation for a phenomenological sociology which strives to uncover the universal structures in the everyday. Following Schütz and Luckmann, the Lebenswelt may be conceived of as what individuals consider to be the given sphere in which they act $(2003$, p. 30). The lifeworld is realised in the "conduct of everyday life" (Jurczyk et al., 2015). This term goes back to Max Weber, and it is defined "primarily as practice (it means the structure of activities that are part of life on an everyday basis)" (Jurczyk et al., 2015, p. 45). The "conduct of everyday life" is understood as both the individually constructed and the institutionalised ordering of everyday life over time. Both endow daily actions with direction, efficiency and meaning and lend stability, coherence and continuity to life as a whole (Kudera, 2001, p. 51). As discussed earlier, the way children conduct their everyday lives is influenced by how they cope with impending developmental tasks; the same holds good for the children's adult reference persons and their respective life tasks.

The individual's activities, with their connections and consequential effects, are at the centre; however, based on patterns of interpretation and biographical schemata, how individuals classify these activities meaningfully cannot be ignored (Hörning, 2001, p. 158). So, beyond subjective representation, the conduct of everyday life is shaped by "classifying practices", which are a symbolic order presenting significant distinctions (Bourdieu, 1996, p. 175). These practices are connected to the social space where children and their parents gain their experiences (both medial and non-medial), build their identities, gain competences for action, and judge, value and classify themselves and their social space. Bourdieu's work on social fields provides a theoretical framework for understanding the interaction between structure and action. Each field values particular sorts of resources (Bourdieu \& Wacquant, 1992), which Bourdieu metaphorically calls "capital". He distinguishes three different types of resources: economic, cultural and social capital. Furthermore, he 
introduces symbolic capital, which is related to honour and recognition and is earned on an individual basis (Bourdieu, 1989). "Thus, on a social field, economic, social and cultural capital is converted to symbolic capital" (Walther, 2014, p. 10).

The composition of the different forms of capital is always unevenly distributed, leading to the formation of specific social milieus. These are shaped by fundamental points of view, which are shared by members of a milieu and through which they distinguish themselves from other social milieus (Weiß, 1997, p. 259). In this way, social milieus demonstrate the social arrangement and structure of a society (Weiß, 1997, p. 246).

The different types of capital are gained through education and socialisation (Bourdieu, 1986). With respect to the social milieu in which social action takes place, Bourdieu explains how certain aims are followed, how certain patterns of orientation and perspectives can be formed, and how particular patterns of action are socially accepted (Weiß, 2000, p. 47). In the framework of socialisation, the patterns of action and orientation that are developed during childhood are culturally rooted, refer to individuals' particular societal status and their social milieu, and shape their specific habitus, which is developed through common social contexts and formed by similar existential backgrounds. As Benson (2016, p. 3) maintains, it is via their habitus that individual agents internalise their experiences of social structure; "habitus-endowed agents constitute and reconstitute the fields of which they are a part" (Benson, 2016, p, 3). In Bourdieu's own words: "The habitus (...) enables an intelligible and necessary relation to be established between practices and a situation, the meaning of which is produced by the habitus through categories of perception and appreciation that are themselves produced by an observable social condition" (Bourdieu, 1996, p. 110). As the habitus operates "at the unconscious level of taken-for-granted assumptions, tastes, and bodily hexis (embodied practice or way of using one's body)" (Benson, 2016, p. 4), it can be understood as an incorporated social structure (Weiß, 1997, p. 246), or as "socialized subjectivity", which can be seen as "a system of dispositions" (Bourdieu, 1996, p. 6). These dispositions are shaped by conditions for the conduct of everyday life that are socially unequal and structurally distributed (Weiß, 1997, p. 246).

Patterns of action are culturally rooted and refer to people's social status. Transformed into everyday opportunities and competences, they influence individual actions and the processes of social and personal identity development and interact with people's subjective ways of making sense of 
societal conditions (Weiß, 2000; Willis, 1977). To conclude, the habitus as a concept following Bourdieu's ideas and provisions has a dual nature: It covers the individual predisposition of a single person on the one hand, but also it incorporates the conditions of the social environment of living and the social surroundings during the process of growing up and socialisation within a social milieu (see also Paus-Hasebrink, 2013, p. 80).

Within this general praxeological perspective on socialisation, we are focusing especially on young people's relation to the media, because these provide a way to deal subjectively with topics arising from developmental and family-related challenges.

When considering the ensemble of practices that are used to conduct everyday life and to cope with everyday challenges, our focus shifts to the individual context. At the same time, we go beyond subjective representations and take into account the social milieus which are-actually or symbolically - at an individual's disposal. In their practical actions, meaning their specific conduct of everyday life, individuals use their capital to seize opportunities in their social spheres (Habermas, 1988, p. 473), such as their working life (employment, income, capital), in politics and law (social order, law, morality), and the private sphere (love, personal relationships, happiness), as efficiently as possible (Weiß, 2000, p. 47). Individuals, including children, attempt to employ their own capital to realise the opportunities of their specific social places (Weiß, 2000 , p. 48 ). The objective structure of socially unequal conditions for action is transformed into the subjective structure of diverging outlines for action. This transformation takes place as a psycho-social process within the identity formation outlined above. It is co-determined by factors such as formal education, gender and the bodily experience of growing up in the framework of an individual biography. In this respect, the media fulfil several functions in the process of a child's socialisation, and these are connected to its specific developmental tasks against the backdrop of its own and its parents' conduct of everyday life within the process of doing family.

\subsubsection{Three Analytic Concepts: Options, Outlines and Competences for Action}

The conduct of everyday life is manifested in social milieus where individuals attempt to realise their specific goals in life, including their own particular plans and wishes. An individual's subjective perception of the 
options for action available, based on his/her social milieu, is crucial here, as is the way an individual forms his/her outlines for action within the framework of the identified options for action and thereby acquires competences for action, which make it possible for him/her to apply his/her resources to the task of realising the outlines for action.

Thus, the following three concepts must be integrated (for an overview see Table 3.1 ):

- Options for action are, on the one hand, related to the individual's specific socio-structural conditions and, on the other, to the socio-structural aspects of society as a whole and its political, economic, cultural and media contexts. Options for action describe the objective characteristics of an individual's social conditions, which are shaped by the rules of the social field(s) in which he/she operates. Options for action represent an ordered arrangement of possible (and impossible) actions.

- Outlines for action are related to subjective perceptions of social conditions and represent the ways in which the subject transforms the objective characteristics of his/her situation into a subjective guide for action. These outlines reflect what makes sense to the subject and indicate the viewpoints from which he/she structures his/ her perceptions and interpretations of the world. Thus, all of the family's or the individual's goals and plans are closely tied to a subjective perception of the social milieu.

- Competences for action are related to the resources at the individual's disposal to accomplish the above outlines for action. As Bourdieu maintains, these competences characterise the material, cultural and social resources available to an individual and serve as cognitive or motivational prerequisites for his/her actions, including the use of media. These competences are reflected in the realisation of the individual's outlines for action.

Based on the options for action, outlines for action and competences for action, it is theoretically and empirically possible to understand the connection between a social milieu, and the subjective structure of making sense of one's life. Our approach to young people's socialisation, as presented here, provides answers through a combined analysis of both the subjective and structural components of practice. It is focused on the lifeworld of a child in the family, where he/she conducts his/her 
Table 3.1 Options for action, outlines for action and competences for action

\begin{tabular}{ll}
\hline Options for action & Related to the individual's specific socio-structural conditions \\
and to the socio-structural aspects of society as a whole (polit- \\
ical, economic, cultural and media contexts) \\
- Describe the objective characteristics of an individual's social \\
conditions, which are shaped by the rules of the social field(s) \\
in which he/she operates \\
- Represent an ordered arrangement of possible (and impossi- \\
ble) actions \\
- Related to subjective perceptions of social conditions \\
- Represent the ways in which the subject transforms the objec- \\
tive characteristics of his/her life situation into a subjective \\
action guide \\
- Reflect what makes sense to the subject and indicate the \\
viewpoints from which he/she structures perceptions and \\
interpretations of the world \\
- Related to the resources at the individual's disposal \\
- Reflect the competences characterised by an individual's \\
material, cultural and social resources \\
- Represent cognitive or motivational prerequisites for an indi- \\
vidual's actions, including the use of media \\
- Reflect competences in the realisation of the individual's \\
outlines for action
\end{tabular}

everyday life and where, starting in early childhood, media activity is given its meaning. This approach helps in examining the everyday structures of a child's life, which are shaped by the family's social situation, in order to describe the "arrangements" for conducting everyday life and the process of doing family. It is through these arrangements that practices, including media practices, are formed and media actions gain structure and meaning. So it is possible to reconstruct the transmission process, namely, how socio-structural conditions transform into an individual's subjective perception and (media-related) actions and how this perception leads to an independent orientation towards the world.

\subsection{Conclusion}

This chapter contends that, in order to understand the role of media within young people's socialisation, we need to conceptualise and operationalise socialisation as the interaction between an individual child and 
the relevant contexts of growing up. Referring to the concept of developmental tasks, we have specified the way children, by coping with these tasks, partly by making use of media, form identity. In order to conceptualise the interaction between the individual child and social contexts, we have focused on the family as the most relevant context for young people's growing up. In order to specify how the underlying social structures in families and other contexts are transformed into a child's personal orientation and identity, we have proposed a praxeological approach that distinguishes three analytical concepts: options for action, outlines for action, and competences for action. Based on these concepts, it is theoretically and empirically possible to understand the connection between a social milieu and the subjective structure of making sense of one's life. In specifying the "arrangements" of the conduct of everyday life and the process of doing family, this approach enables us to examine the everyday structures of an adolescent's life. It is through these arrangements that practices, including media practices, are formed and media actions gain structure and meaning. So it is possible to reconstruct the transmission process, namely how socio-structural conditions transform into an individual's subjective perception and (media-related) actions and how this perception leads to an independent orientation towards the world.

As presented in this chapter, our theoretical approach provides a fruitful basis for research on the role of media within young people's socialisation. The role of other contexts we empirically investigated in our longitudinal study, such as peers, romantic partners, kindergarten or schools, professional training, will be discussed in more detail in Chapter 6.

The next chapter (Chapter 4) illustrates both the methods we applied in our longitudinal study on children's, or respectively adolescents', socialisation in socially disadvantaged families and how this approach can be operationalised.

\section{REFERENCES}

Abels, H. (2015). Der Beitrag der Soziologie zur Sozialisationsforschung [Contribution of sociology on socialisation]. In K. Hurrelmann, U. Bauer, M. Grundmann, \& S. Walper (Eds.), Handbuch Sozialisationsforschung [Handbook of socialisation research] (8th Rev. ed., pp. 50-79). Weinheim, Germany: Beltz. 
Albert, M., Hurrelmann, K., \& Quenzel, G. (2015). Jugend 2015: Eine pragmatische Generation im Aufbruch. 17. Shell Jugendstudie [Adolescence 2015: A pragmatic generation moving on 17th Shell adolescence study]. Frankfurt am Main, Germany: S. Fischer Verlag.

Ang, I. (2006). Radikaler Konstruktivismus und Ethnografie in der Rezeptionsforschung [Radical constructivism and ethnography in reception research]. In A. Hepp \& R. Winter (Eds.), Kultur-Medien - Macht. Cultural Studies und Medienanalyse [Culture-media-power: Cultural studies and the analysis of media] (3rd ed., pp. 61-79). Wiesbaden, Germany: VS Verlag für Sozialwissenschaften.

Arnett, J. J. (2006). Emerging adulthood: Understanding the new way of coming of age. In J. J. Arnett \& J. L. Tanner (Eds.), Emerging adults in America: Coming of age in the 21st century (pp. 3-19). Washington, DC: American Psychological Association.

Arnett, J. J. (2007). Emerging adulthood: What is it and what is it good for. Child Development Perspectives, 1(2), 68-73.

Benson, R. (2016). Bourdieu, Pierre. In K. B. Jensen \& R. T. Craig (Eds.), International encyclopaedia of communication theory and philosophy. Hoboken, NJ: Wiley.

Berger, P. L., \& Luckmann, T. (1966). The social construction of reality: A treatise in the sociology of knowledge. London, UK: Penguin Books.

Bourdieu, P. F. (1977). Outline of a theory of practice. New York, NY: University Press.

Bourdieu, P. F. (1986). The forms of capital. In J. Richardson (Ed.), Handbook of theory and research for the sociology of education (pp. 241-258). New York, NY: Greenwood Publishing Group.

Bourdieu, P. F. (1989). Social space and symbolic power. Sociological Theory, $7(1), 14-25$.

Bourdieu, P. F. (1996). Distinction: A social critique of the judgement of taste (8th ed., R. Nice, Trans.). London, UK: Routledge.

Bourdieu, P. F., \& Waquant, L. (1992). An invitation to reflexive sociology. Chicago, IL: The University of Chicago Press.

Bronfenbrenner, U. (1977). Toward an experimental ecology of human development. American Psychologist, 32(7), 513-531.

Bronfenbrenner, U. (1979). The ecology of human development: Experiments by nature and design. Cambridge, MA: Harvard University Press.

Brown, B. B. (2004). Adolescents' relationships with peers. In R. J. Lerner \& L. D. Steinberg (Eds.), Handbook of adolescent psychology (2nd ed., pp. 363-394). New York; NY: Wiley.

Bruner, J. S., Goodnow, J., \& Austin, G. A. (1962). A study of thinking. New York, NY: Wiley (Science Editions, A Wiley Publication in Psychology). 
Buckingham, D. (2008). Children and media: A cultural studies approach. In K. Drotner \& S. Livingstone (Eds.), The international handbook of children, media and culture (pp. 219-236). Los Angeles, CA, London, UK, and New Dehli, India: Sage.

Charlton, M., \& Neumann, K. (1986). Medienkonsum und Lebensbewältigung in der Familie: Methode und Ergebnisse der strukturanalytischen Rezeptionsforschung. Mit fünf Darstellungen [Media consumption and coping with life: Methods and outcomes of structure-analytical reception research]. München, Germany: Psychologie-Verlags-Union.

Cooley, C. H. (1902). Human nature and the social order. New Brunswick, Canada: Transaction Books.

Drotner, K., \& Livingstone, S. (Eds.). (2008). The international handbook of children, media and culture. London, UK, Thousand Oaks, CA, and New Dehli, India: Sage.

Durkheim, É. (1972). Selected writings. Edited, translated, and with an introduction by A. Giddens. Cambridge, UK: Cambridge University Press.

Erikson, E. H. (1959). Identity and the life cycle. New York, NY: International Universities Press.

Erikson, E. H. (1968). Identity: Youth and crisis. New York, NY: Norton.

Fend, H. (2005). Entwicklungspsychologie des Jugendalters. Ein Lebrbuch für pädagogische und psychologische Berufe [Developmental psychology of adolescence: A textbook for pedagogic and psychologic professionals] (3rd ed.). Wiesbaden, Germany: VS Verlag.

Friedemann, S., \& Hoffmann, D. (2013). Musik im Kontext der Bearbeitung von Entwicklungsaufgaben des Jugendalters [Music in the context of coping with developmental tasks of adolescence]. In R. Heyer, S. Wachs, \& C. Palentien (Eds.), Handbuch Jugend - Musik - Sozialisation [Handbook of adolescence-music—socialisation] (pp. 371-393). Wiesbaden, Germany: Springer.

Furlong, J., \& Davies, C. (2012). Young people, new technologies and learning at home: Taking context seriously. Oxford Review of Education, 38(1), 45-62.

Gesell, A. (1933). Maturation and the patterning of behaviour. In C. Murchison (Ed.), The international university series in psychology: A handbook of child psychology (2nd ed., pp. 209-235). Worcester, MA: US Clark University Press.

Goffman, I. (1959). The presentation of self in everyday life. New York, NY: Doubleday.

Goldberg, S., Grusec, J. E., \& Jenkins, J. M. (1999). Confidence in protection: Arguments for a narrow definition of attachment. Journal of Family Psychology, 13(4), 475-483.

Göppel, R. (2005). Das Jugendalter. Entwicklungsaufgaben - Entwicklungskrisen - Bewältigungsformen [Adolescence: Developmental tasks-Developmental crises-Forms of coping]. Stuttgart, Germany: Verlag W. Kohlhammer. 
Grusec, J. E., \& Hastings, P. D. (2015). Preface. In J. E. Grusec \& P. D. Hastings (Eds.), Handbook of socialization: Theory and research (2nd ed., pp. XI-XIII). New York, NY: Guilford Press.

Habermas, J. (1988). Theorie des kommunikativen Handelns. Band 1 und 2 [Theory of communicative action: Volume 1 and 2] (4th Rev. ed.). Frankfurt am Main, Germany: Suhrkamp.

Hasebrink, U., \& Paus-Hasebrink, I. (2013). Trends in children's consumption of media. In D. Lemish (Ed.), The Routledge international handbook of children, adolescents and media (pp. 31-38). Milton Park and London, UK: Routledge and Taylor \& Francis.

Havighurst, R. J. (1972). Developmental tasks and education (3rd ed.). New York, NY: McKay.

Heckhausen, J., \& Schulz, R. (1999). Biological and societal canalizations and individuals' developmental goals. In J. Brandtstadter \& R. Lerner (Eds.), Action and self-development: Theory and research through the life-pan (pp. 67-103). Thousand Oaks, CA, London, UK, and New Dehli, India: Sage.

Hoffman, E. (1994). The drive for self: Alfred Adler and the founding of individual psychology. New York, NY: Addison-Wesley.

Hoffmann, D., Krotz, F., \& Reißmann, W. (2017). Mediensozialisation und Mediatisierung. Problemstellung und Einführung [Media socialisation and mediatization]. In D. Hoffmann, F. Krotz, \& W. Reißmann (Eds.), Mediatisierung und Mediensozialisation. Prozesse - Räume - Praktiken [Mediatization and media socialisation: Processes-spaces-practices] (pp. 3-18). Wiesbaden, Germany: Springer.

Hörning, K. H. (2001). Experten des Alltags [Experts in everyday life]. Weilerswist, Germany: Velbrück.

Hradil, S. (1987). Sozialstrukturanalyse in einer fortgeschrittenen Gesellschaft [Analysis of social structure in an advanced society]. Opladen, Germany: Leske und Budrich.

Hurrelmann, K. (2009). Social structure and personality development. Cambridge, UK: Cambridge University Press.

Hurrelmann, K. (2010). Lebensphase Jugend. Eine Einführung in die sozialwissenschaftliche Jugendforschung [Life period adolescence: An introduction into social scientific youth research] (10th ed.). Weinheim and München, Germany: Juventa Verlag.

Hurrelmann, K., \& Bauer, U. (2015). Das Modell des produktiv realitätsverarbeitenden Subjekts [The model of the subject productively processing reality]. In K. Hurrelmann, U. Bauer, M. Grundmann, \& S. Walper (Eds.), Handbuch Sozialisationsforschung [Handbook of socialisation research] (8th Entirely Rev. ed., pp. 144-161). Weinheim, Germany: Beltz.

Hurrelmann, K., Bauer, U., Grundmann, M., \& Walper, S. (Eds.). (2015). Handbuch Sozialisationsforschung [Handbook of socialisation research] (8th Entirely Rev. ed.). Weinheim, Germany: Beltz. 
Huston, A. C., \& Wright, J. C. (1997). Mass media and children's development. In I. Sigel \& K. A. Renninger (Eds.), Handbook of child psychology: Child psychology in practice (5th ed., Vol. 4., pp. 999-1058). New York, NY: Wiley.

James, A. (2013). Socialising children. Basingstoke, UK: Palgrave Macmillan.

James, A., Jenks, C., \& Prout, A. (1998). Theorizing childhood. Cambridge, MA: Polity Press.

Jennings, N., \& Wartella, E. (2013). Technology and the family. In A. Vangelisti (Ed.), The handbook of family communication (2nd ed., pp. 448-462). Mahwah, NJ: Lawrence Erlbaum Associates.

Jordan, A. B. (2003). A family systems approach to examining the role of the internet in the home. In J. Turow \& A. L. Kavanaugh (Eds.), The wired homestead: MIT press sourcebook on the internet and the family (pp. 141-160). Cambridge, MA: MIT Press.

Jurczyk, K., Voß, G. G., \& Weihrich, M. (2015). Conduct of everyday live in subjective-oriented sociology. In E. Schraube \& C. Højholt (Eds.), Psychology and conduct of everyday life (pp. 34-64). London, UK: Routledge.

Kimmel, D. C., \& Weiner, I. B. (1995). Adolescence: A developmental transition (2nd ed.). New York, NY: Wiley.

Krappmann, L. (2016). Soziologische Dimensionen der Identität. Strukturelle Bedingungen für die Teilnabme an Interaktionsprozessen [Sociological dimensions of identity processes]. Stuttgart, Germany: Klett-Cotta.

Krotz, F., \& Hepp, A. (2013). A concretization of mediatization: How mediatization works and why, mediatized worlds' are a helpful concept for empirical mediatization research. European Journal for the Philosophy of Communication, 3(2), 37-152.

Krueger, R., \& Johnson, W. (2010). Behavioral genetics and personality: A new look at the integration of nature and nurture. In O. P. John, R. W. Robins, \& L. A. Pervin (Eds.), Handbook of personality: Theory and research (3rd ed., pp. 287-310). New York, NY: Guilford.

Kudera, W. (2001). Anpassung, Rückzug oder Restrukturierung - Zur Dynamik alläglicher Lebensführung in Ostdeutschland [Adaption, retreat or restructuring-On dynamic conduct of everyday life in Eastern Germany]. In B. Lutz (Ed.), Entwicklungsperspektiven von Arbeit [Perspectives on development of work] (pp. 46-82). Berlin, Germany: Akademie Verlag.

Laible, D., Thomson, R. A., \& Froimson, J. (2015). Early socialization: The influence of close relationships. In J. E. Grusec \& P. D. Hastings (Eds.), Handbook of socialization: Theory and research (pp. 35-59). New York, NY: Guilford Press.

Lamb, M. E., Ketterlinus, R. D., \& Fracasso, M. P. (1992). Parent-child relationships. In M. H. Bornstein \& M. E. Lamb (Eds.), Developmental psychology: An advanced textbook (pp. 465-518). Mahwah, NJ: Lawrence Erlbaum Associates. 
Lange, A. (2015). Sozialisation in der mediatisierten Gesellschaft [Socialisation in a mediatized society]. In K. Hurrelmann, U. Bauer, M. Grundmann, \& S. Walper (Eds.), Handbuch Sozialisationsforschung [Handbook of socialisation research] (8th Entirely Rev. ed., pp. 537-556). Weinheim, Germany: Beltz.

Lauricella, A. R., Cingel, D. P., Blackwell, C., Wartella, E., \& Conway, A. (2014). Mobile generation: Youth and adolescent ownership and use of new media. Communication Research Reports, 31(4), 357-364.

Lemish, D. (2007). Children and television: A global perspective. Malden, MA: Blackwell.

Lemish, D. (Ed.). (2013). The Routledge international handbook of children, adolescents and media. Milton Park and London, UK: Routledge and Taylor \& Francis.

Livingstone, S. (2014). The mediatization of childhood and education: Reflections on the class. In L. Kramp, N. Carpentier, A. Hepp, I. T. Trivundža, H. Nieminen, R. Kunelius, ..., R. Kilborn (Eds.), Media practice and everyday agency in Europe (pp. 55-68). Bremen, Germany: Edition lumière.

Livingstone, S., \& Bovill, M. (Eds.). (2001). Children and their changing media environment: A European comparative study. Mahwah, NJ: Lawrence Erlbaum Associates.

Livingstone, S., d'Haenens, L., \& Hasebrink, U. (2001). Childhood in Europe: Contexts for comparison. In S. Livingstone \& M. Bovill (Eds.), Children and their changing media environment: A European comparative study (pp. 3-30). Mahwah, NJ: Lawrence Erlbaum Associates.

Livingstone, S., \& Lunt, P. (2014). Mediatization: An emerging paradigm for media and communication studies. In K. Lundby (Ed.), Mediatization of communication: Handbook of communication science (pp. 703-723). Berlin, Germany: Walter de Gruyter.

Livingstone, S., \& Sefton-Green, J. (2016). The class: Living and learning in the digital age. New York, NY: New York University Press.

Lull, J. (1980). Family communication patterns and the social uses of television. Human Communication Research, 6(3), 197-209.

Lundby, K. (2014). Mediatization of communication. In K. Lundby (Ed.), Mediatization of communication: Handbook of communication science (pp. 3-35). Berlin, Germany: Walter de Gruyter.

Maccoby, E. E. (2015). Historical overview of socialization research and theory. In J. E. Grusec \& P. D. Hastings (Eds.), Handbook of socialization: Theory and research (2nd ed., pp. 3-32). New York, NY: Guilford Press.

Marsh, J., Brooks, G., Hughes, J., Ritchie, L., Roberts, S., \& Wright, K. (2005). Digital beginnings: Young children's use of popular culture, media and new technologies. Report of the 'Young Children's Use of Popular Culture, Media and New Technologies' study, funded by BBC Worldwide and the 
Esmée Fairbairn Foundation. Sheffield, UK: Literacy Research Centre of the University of Sheffield, BBC Worldwide and Esmée Fairbairn. Retrieved from http://www.digitalbeginnings.shef.ac.uk/DigitalBeginningsReport.pdf.

Mayer, A. (2017). Sigmund Freud. Zur Einführung [ Sigmund Freud: An introduction]. Hamburg, Germany: Junius Verlag.

Mayseless, O., \& Keren, E. (2014). Finding a meaningful life as a developmental task in emerging adulthood: The domains of love and work across cultures. Emerging Adulthood, 2(1), 63-73.

Mead, G. H. (1934). Mind, self, and society. Chicago, IL: The University Chicago Press.

Morgan, D. H. J. (2011). Rethinking family practices. Basingstoke, UK: Palgrave Macmillan.

Morley, D. (1992). Television, audiences and cultural studies. London, UK: Routledge.

Nathanson, A. I. (2013). Media and the family context. In D. Lemish (Ed.), The Routledge international handbook of children, adolescents and media (pp. 299306). London, UK: Routledge.

Neal, J. W., \& Neal, Z. P. (2013). Nested or networked? Future directions for ecological systems theory. Social Development, 22(4), 722-737.

Noller, P. \& Atkin, S. (2014). Family life in adolescence. Berlin, Germany and Boston, MA: Sciendo Migration.

Oerter, R., \& Dreher, E. (2008). Jugendalter [Adolescence]. In R. Oerter \& L. Montada (Eds.), Entwicklungspsychologie [Developmental psychology] (6th Entirely Rev. ed., pp. 271-332). Weinheim, Germany and Basel, Switzerland: Beltz.

Packer, M. J. (2017). Child development: Understanding a cultural perspective. London, UK, Los Angeles, CA, New Dehli, India, and Singapore: Sage.

Parsons, T. (1951). The social system. New York, NY: Free Press.

Paus-Hasebrink, I. (2010). Das Social Web im Kontext der Entwicklungsaufgaben junger Menschen [Social media in the context of developmental tasks of young people]. Medien Journal: Zeitschrift für Kommunikationskultur, 34(4), 20-34.

Paus-Hasebrink, I. (2013). Audiovisuelle und Online-Kommunikation Theoretische Wege zur Analyse der komplexen Zusammenhänge von Produktions-, Angebots- und Aneignungsweisen [Audiovisual and online-communication]. In I. Paus-Hasebrink, S. Trültzsch, A. Pluschkowitz, \& C. Wijnen (Eds.), Integrative AV- und Online-Kommunikationsforschung. Perspektiven - Positionen - Projekte [Integrative AV- and online-communication research: Perspectives-Positions-Projects] (pp. 60-99). Baden-Baden, Germany: Nomos.

Paus-Hasebrink, I. (2017). Praxeologische (Medien-)Sozialisationsforschung [Praxeological approach on media socialisation research]. In D. Hoffmann, F. Krotz, \& W. Reißmann (Eds.), Mediatisierung und Mediensozialisation. 
Prozesse - Räume - Praktiken [Mediatization and media socialisation: Processes-Spaces-Practices] (pp. 103-118). Wiesbaden, Germany: Springer Fachmedien.

Paus-Hasebrink, I. (2018). The role of media within children's socialization: A praxeological approach. Communications: The European Journal of Communication Research. Ahead of print, 17.10.2018 (pp. 1-20). DOI: https://doi.org/10.1515/commun-2018-2016.

Paus-Hasebrink, I., Bauwens, J., Dürager, A. E., \& Ponte, C. (2013). Exploring types of parent-child relationship and internet use across Europe. Journal of Children and Media-JOCAM, 7(1), 114-132.

Paus-Hasebrink, I., \& Kulterer, J. (2014). Praxeologische Mediensozialisationsforschung. Langzeitstudie $z u$ sozial benachteiligten Heranwachsenden [Praxeological media socialisation research: A longitudinal study regarding socially disadvantaged adolescents] Assisted by P. Sinner. Baden-Baden, Germany: Nomos.

Piaget, J. (1980). Psychologie der Intelligenz [Psychology of cognitive development]. Stuttgart, Germany: Klett-Cotta.

Piotrowski, J. T., \& Valenburg, P. M. (2016). Psychology, development. In K. B. Jensen \& R. T. Craig (Eds), International encyclopedia of communication theory and philosophy. Hoboken, NJ: Wiley.

Prout, A. (2008). Culture-nature and the construction of childhood. In K. Drotner \& S. Livingstone (Eds.), The international handbook of children, media and culture (pp. 21-35). Los Angeles, CA, London, UK, and New Dehli, India: Sage.

Prout, S., Anderson, A. A., Gentile, D. A., Warburton, W., Saleem, M., Groves, C. L., \& Brown, S. C. (2015). Media as agents of socialization. In J. E. Grusec \& P. D. Hastings (Eds.), Handbook of socialization: Theory and research (2nd ed., pp. 276-300). New York, NY: Guilford Press.

Quenzel, G. (2015). Entwicklungsaufgaben und Gesundheit im Jugendalter [Developmental tasks and health during adolescence]. Weinheim, Germany: Beltz Juventa.

Rideout, V. J. (2016). Measuring time spent with media: The common sense census of media use by US 8- to 18-year-olds. Journal of Children and Media-JOCAM, 1O(1), 138-144.

Rideout, V., Foehr, U. G., \& Roberts, D. F. (2010). Generation M²: Media in the lives of 8- to 18-year-olds: A Kaiser family foundation study. Menlo Park, CA: The Henry J. Kaiser Family Foundation. Retrieved from https://kaiserfamilyfoundation.files.wordpress.com/2013/04/8010.pdf.

Schofield Clark, L. (2013). The parent app: Understanding families in the digital age. Oxford, UK: University Press.

Schöllgen, G. (1998). Max Weber. München, Germany: Beck.

Schütz, A., \& Luckmann, T. (2003). Strukturen der Lebenswelt [Structures of the lifeworld]. Konstanz, Germany: UVK Verlagsgesellschaft. 
Silverstone, R. (2002). Complicity and collision in the mediation of everyday life. New Literary History, 33(4), 745-764.

Simmel, G. (1908). Soziologie. Untersuchungen über die Formen der Vergesellschaftung [Sociology: Studies on the forms of socialisation]. Berlin, Germany: Duncker \& Humblot.

Skaar, H. (2009). Branded selves. Journal of Children and Media-JOCAM, $3(3), 249-267$.

Smetana, J. G., Robinson, J., \& Rote, W. (2015). Socialization in adolescence. In J. E. Grusec \& P. D. Hastings (Eds.), Handbook of socialization: Theory and research (2nd ed., pp. 60-84). New York, NY: Guilford Press.

Steinberg, L. (2005). Adolescence (7th ed.). New York, NY: McGraw-Hill.

Subrahmanyam, K., \& Šmahel, D. (2011). Digital youth: The role of media in development. New York, NY: Springer.

Vandewater, E. A. (2013). Ecological approaches to the study of media and children. In D. Lemish (Ed.), The Routledge international handbook of children, adolescents and media (pp. 46-53). Milton Park and London, UK: Routledge and Taylor \& Francis.

Walther, M. (2014). Repatriation to France and Germany: A comparative study based on Bourdieu's theory of practice. Wiesbaden, Germany: Springer Gabler.

Wartella, E., Beaudoin-Ryan, L., Blackwell, C. K., Cingel, D., Hurwitz, L. B., \& Lauricella, A. R. (2016). What kind of adults will our children become? The impact of growing up in a media-saturated world. Journal of Children and Media-JOCAM, 10(1), 13-20.

Weiß, R. (1997). Auf der Suche nach kommunikativen Milieus [Searching for communicative milieus]. In H. Scherer \& H.-B. Brosius (Eds.), Zielgruppen, Publikumssegmente, Nutzergruppen [Target groups, audience segments, user groups] (pp. 239-261). München, Germany: Reinhard Fischer.

Weiß, R. (2000). Praktischer Sinn, soziale Identität und FernSehen [Practical sense, social identity and tele-vision]. Medien und Kommunikationswissenschaft, 48(1), 42-62.

Weiß, R. (2001). Fern-Sehen im Alltag. Zur Sozialpsychologie der Medienrezeption [Tele-vision in everyday life: On social psychology of media reception]. Opladen, Germany: Westdeutscher Verlag.

Willis, P. (1977). Learning to labor: How working class kids get working class jobs. Tiptree, UK: Anchor Press.

Wilson, B. J., \& Drogos, K. L. (2013). The mass media and family communication. In A. Vangelisti (Ed.), The handbook of family communication (2nd ed., pp. 424-447). Mahwah, NJ: Lawrence Erlbaum Associates.

Wygotski, L. S. (1977). Denken und Sprechen [Thinking and speaking]. Edited by J. Helm with an introduction by T. Luckmann. Frankfurt am Main, Germany: Fischer. 
Open Access This chapter is licensed under the terms of the Creative Commons Attribution 4.0 International License (http://creativecommons.org/licenses/ by $/ 4.0 /$ ), which permits use, sharing, adaptation, distribution and reproduction in any medium or format, as long as you give appropriate credit to the original author(s) and the source, provide a link to the Creative Commons licence and indicate if changes were made.

The images or other third party material in this chapter are included in the chapter's Creative Commons licence, unless indicated otherwise in a credit line to the material. If material is not included in the chapter's Creative Commons licence and your intended use is not permitted by statutory regulation or exceeds the permitted use, you will need to obtain permission directly from the copyright holder.

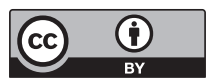

